\title{
SHORT NOTES \\ Biological Aspects of Dirphia moderata (Lepidoptera: Saturniidae) on Eucalyptus cloeziana and Psidium guajava
}

\author{
Fabricio Fagundes Pereira ${ }^{1}$, João Paulo de Mello Felipe ${ }^{1}$, Glauco da Cruz Canevari ${ }^{1}$, Olaf \\ Hermann Hendrik Mielke ${ }^{2}$, José Cola Zanuncio ${ }^{1}$ and José Eduardo Serrão $^{3}$ \\ ${ }^{1}$ Departamento de Biologia Animal/BIOAGRO; Universidade Federal de Viçosa; 36.571-000; zanuncio@ufv.br; \\ Viçosa - MG - Brasil. ${ }^{2}$ Departamento de Zoologia; Setor de Ciências Biológicas; Universidade Federal do Paraná; \\ C. P.: 19020; 81531-980; Curitiba - PR - Brasil. Contribuição número 1554 do Departamento de Zoologia; \\ Universidade Federal do Paraná. ${ }^{3}$ Departamento de Biologia Geral; Universidade Federal de Viçosa; 36.571-000; \\ Viçosa - MG - Brasil
}

\begin{abstract}
An egg mass of Dirphia moderata Bouvier was collected around a branch of Eucalyptus cloeziana to register the occurrence and to study the biological aspects of this species fed with leaves of $\mathrm{E}$. cloeziana or $\mathrm{P}$. guajava at $25 \pm 2^{\circ}$ $C$, relative humidity of $60 \pm 10 \%$ and photo phase of $12 \mathrm{~h}$. The duration and viability of the larva stage of $\mathrm{D}$. moderata was 56.01 days and $80.00 \%$ and 55.79 days and $72.5 \%$ for its caterpillars fed with the first and second host plants, respectively. The duration (days) and viability (\%) of the pupae stage of this insect were 37.64 and 87.00 fed with E. cloeziana and 49.93 and 87.75 with P. guajava, respectively. The average longevity (days) was 6.79 and 8.85 for males and 10.48 and 10.09 for females with E. cloeziana and $\mathrm{P}$. guajava, respectively. Each female of D. moderata laid 121.71 and 112.00 eggs with an incubation period (days) of 18.14 and 17.79 and viability (\%) of 75.0 and 70.0 with the first and the second hosts, respectively.
\end{abstract}

Key words: Eucalyptus defoliator, Saturniidae, Dirphia

Lepidoptera defoliators are found in the eucalyptus plantations and its importance is increasing due to frequent outbreaks and damage (Zanuncio et al., 2003, Oliveira et al., 2005). Species of the genus Dirphia Hübner, [1819] are considered secondary pests of the eucalyptus but they can become important due to their high reproductive capacity in eucalyptus plants and adaptation to many species of the family Myrtaceae. Dirphia sp. was registered in Eucalyptus saligna in the Municipality of Piracicaba, State of São Paulo and Dirphia avia (Stoll, 1780) and Dirphiopsis trisignata (C. Felder and Rogenhofer, 1874)
(Saturniidae: Hemileucinae) in eucalyptus plantations in the Municipalities of Caçapava and São José dos Campos, São Paulo (Bittencourt et al., 2003). Dirphia avicula (Draudt, 1930) was collected in the Municipality of Montes Claros, Minas Gerais with its biological characteristics being studied with $E$. urophylla (Zanuncio et al., 1994). D. araucariae Jones, 1908 , D. baroma (Schaus, 1906), D. fornax (Druce, 1903), D. muscosa Schaus, 1898 and D. ursina Walker, 1855 were captured with light traps and illuminated cloths in different regions of the State of Rio Grande do Sul, Brazil (Corseuil et al., 2002).

\footnotetext{
${ }^{*}$ Author for correspondence
} 
An egg mass of a Lepidoptera was found in March 2004 in a plant of E. cloeziana in the experimental area of the Laboratory of Forest Entomology of the Federal University of Viçosa, in Viçosa, State of Minas Gerais, Brazil with latitude of $20^{\circ} 45^{\prime} \mathrm{S}$, longitude of $42^{\circ} 51^{\prime} \mathrm{W}$ and altitude of 651 meters. This egg mass was conditioned in a $10 \mathrm{~cm}$ diameter by $1.2 \mathrm{~cm}$ height plastic Petri dish with a cotton wad soaked with distilled water and maintained at $25 \pm 2^{\circ} \mathrm{C}$, relative humidity of $60 \pm$ $10 \%$ and $12 \mathrm{~h}$ photo phase. Five groups of twentyfive caterpillars were put in $10 \mathrm{~cm}$ diameter by 10 $\mathrm{cm}$ height $(500 \mathrm{ml})$ plastic pots with their covers substituted by a plastic screen. Leaves of $E$. cloeziana with its petiole wrapped by moistened cotton pads in the glass tubes of anesthetic type were put inside these pots and changed daily. These caterpillars were transferred to $30 \times 30 \times 30$ $\mathrm{cm}$ screened cages with wood bottom and glass covers at the beginning of the fourth instar due to their size. Pupae of this Lepidoptera were put in plastic pots $(500 \mathrm{ml})$ with moistened soil. Ten adults of this species were mounted, photographed and identified as Dirphia moderata Bouvier, 1919 (Lepidoptera: Saturniidae). This species was reported as D. avicula on E. urophylla (Zanuncio et al., 1994) and this synonymy was corrected after a revision of this genus. Six pairs of this Lepidoptera were individualized in similar cages with three of then on branches of E. cloeziana and the others on Psidium guajava branches, all wrapped by moistened cotton pads to obtain eggs, larvae, pupae and adults of this insect.

D. moderata was observed in the second generation and its mating occurred during the night while adults this species stayed quiet during the day. This species laid its eggs in masses on eucalyptus or guava leaves, on the screen or on the wood of the cages. These eggs were flat with a milk color, which changed along the time (Figure 1A). The caterpillars of D. moderata presented gregarious behavior in the first instars (Figure 1B) with those of each group showing similar metabolism (feeding, resting, ecdysis and pupation). The caterpillars of this species moved in the interior of the cages in single lines with all individuals following those that went ahead. This type of behavior was similar to that reported for $D$. eumedidoides with leaves of $E$. grandis (Santos et al., 1993) and Euselasia hygenius (Stoll, 1787) (Riodinidae) with E. urophylla (Zanuncio et al., 1995).
Caterpillars of $D$. moderata presented larger leaf consumption of $P$. guajava and E. cloeziana in the fifth and sixth instars, which was also reported for this species and Cerodiphia rosacordis (Dirphia) (Walker, 1855) with E. urophylla leaves (Zanuncio et al., 1992; Zanuncio et al., 1994). Fifth instar caterpillars of $D$. moderata was more urticant what could be due to an increase on the number of ramifications of the bristles and when touched they bend their body and rolled up. Sixth instar caterpillars, practically, did not present modifications compared to those of the previous instars but their head are red brown color with an epicranial suture (in form of an inverted Y). The pre-pupae followed the sixth instar when the caterpillars of $D$. moderata stopped feeding and decreased in length, curved their body, the abdomen changed to a red color and they stopped being urticant (Figure 1D). The pupation of $D$. moderata occurred under the substratum at the bottom of the rearing cages where the caterpillars weaved a cocoon. This indicated that it should happen in the soil, among the debris and leaves under eucalyptus plants. The pupa of $D$. moderata was brown at the beginning of this stage and brown-dark after $24 \mathrm{~h}$ (Figure 1E). The outline of its antennas and eyes were clearly observed in this stage. The females of this species differed from the males because they presented more robust abdomen, filiform antennae with yellow color, first pairs of wings ash-red with a stain black and the back wings with two dark lines perpendicular to the veins and a black central stain between these lines. Males of $D$. moderata presented yellow bipectinate antennae and wings similar to those of the females but with brown-red color (Figure 1F). The morphological and behavioral characteristics of $D$. moderata were similar to those of $C$. rosacordis (Zanuncio et al., 1992). However, the first species could be differentiated from the last one by the color of its espiracules, which are white in D. moderata and red in D. rosacordis. Besides, third instars caterpillars were, mainly, red for the first and white green for the second species (Figure 1C).

This is the first report of D. moderata feeding on $E$. cloeziana and $P$. guajava. The caterpillars of this species presented six instars with E. cloeziana with a total duration of 56.01 days and viability of $80 \%$ for its larval stage. The pupa stage lasted 37.64 days with a viability of $87 \%$. Their adults showed longevity of 6.79 and 10.48 days for the males and females, respectively. Each female laid 
121.71 eggs with an incubation period of 18.14 days and viability of $75 \%$. The caterpillars of $D$. moderata also presented six instars with $P$. guajava, but the larva stage lasted 55.79 days with a larvae viability of $72.5 \%$ with this plant. The duration and viability of the pupae stage were 49.93 days and $87.75 \%$ for the caterpillars of this
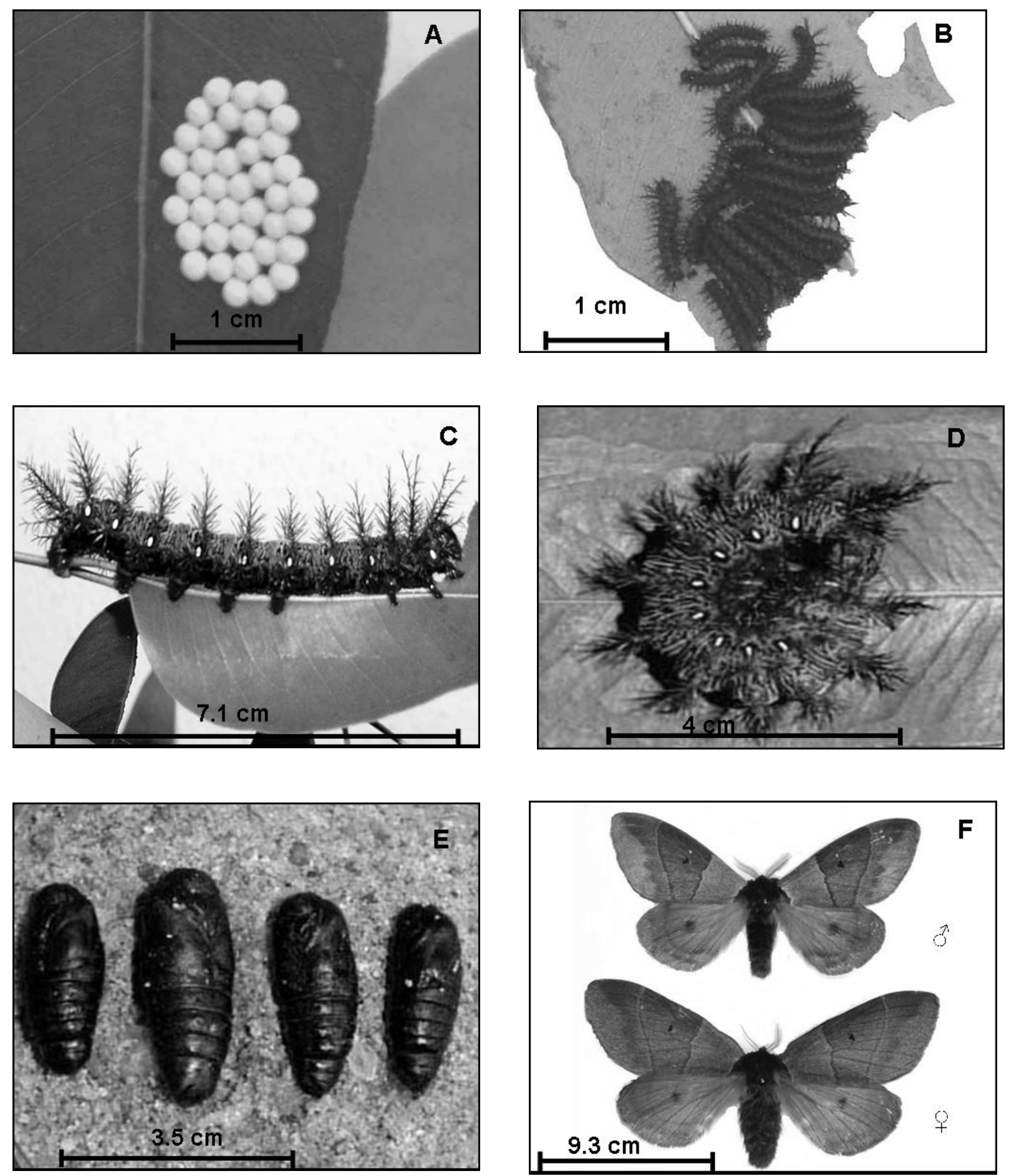

Figure 1 - Dirphia moderata. Eggs (A), second instar caterpillars with gregarious behavior (B), sixth instar caterpillar (C), pre-pupae (D), pupae (E) and adults (F). 
These data were similar to those reported for $D$. avicula with E. urophylla that presented a duration and viability of the larval stage of 50.63 days and $84.5 \%$; 50.65 days and viability of $100 \%$ for the pupae stage; longevity of 5.8 and 9.10 days for the males and females, respectively, and 95.60 eggs per female with an egg incubation period of 17.4 and viability of $70.7 \%$ (Zanuncio et al., 1994).

The biotic parameters of $D$. moderata showed that this species has potential to cause significant damage to Myrtaceae, especially, eucalyptus, in a similar manner as reported for other Lepidoptera defoliators such as $P$. denticulata (Santos et al., 1982) and A. sericea (Santos et al., 1985). These species were considered secondary species but they became primary ones. This justified additional studies to determine biological aspects of $D$. moderata with other main eucalyptus species used in reforestation in Brazil such as E. urophylla and $E$. grandis.

\section{ACKNOWLEDGEMENTS}

We thank the "Conselho Nacional de Desenvolvimento Científico e Tecnológico (CNPq), Coordenação de Aperfeiçoamento de Pessoal de Nível Superior (CAPES)" and "Fundação de Amparo à Pesquisa do Estado de Minas Gerais (FAPEMIG)".

\section{RESUMO}

Postura de Dirphia moderata Bouvier, 1919 (Lepidoptera: Saturniidae) foi coletada ao redor de um ramo de Eucalyptus cloeziana na área experimental do Laboratório de Entomologia Florestal da Universidade Federal de Viçosa, em Viçosa, Minas Gerais. O objetivo foi registrar a ocorrência e estudar aspectos biológicos de $D$. moderata alimentada com folhas de E. cloeziana ou Psidium guajava na temperatura de $25 \pm 2^{\circ} \mathrm{C}$, umidade relativa de $60 \pm 10 \%$ e fotofase de 12 horas. A duração e a viabilidade larval foram de 56,01 dias e $80,00 \%$ e de 55,79 dias e $72,50 \%$ para lagartas de $D$. moderata alimentadas com $E$. cloeziana ou Psidium guajava, respectivamente. A duração (dias) e a viabilidade (\%) do estágio de pupa foram de 37,64 e 87,00 para este inseto com E. cloeziana e de 49,93 e 87,75 com $P$. guajava, respectivamente. A longevidade média (dias) foi de 6,79 e 8,85 para machos e de 10,48 e 10,09 para fêmeas desse inseto com $E$. cloeziana e $P$. guajava, respectivamente. Cada fêmea de $D$. moderata depositou 121,71 e 112,00 ovos com período de incubação (dias) de 18,14 e 17,79 e viabilidade (\%) de 75,0 e 70,0 com essas plantas hospedeiras, respectivamente.

\section{REFERENCES}

Bittencourt, M.A.; Boaretto, L.; Serafim. I.; Berti Filho, E. (2003), Fauna de Lepidoptera associada a um ecossistema natural no estado de São Paulo. Arquivos do Instituto Biológico de São Paulo, 70, 85-87.

Corseuil, E.; Specht, A.; Lang, C. (2002), Saturniídeos (Lepidoptera: Saturniidae) registrados para o Rio Grande do Sul, Brasil. I. Hemileucinae. Biociências, 10, 147-155.

Oliveira, H.N.; Zanuncio, J.C.; Pedruzzi, E.P., Espindula, M.C. (2005). Rearing of Thyrinteina arnobia (Lepidoptera: Geometridae) on guava and eucalyptus in laboratory. Brazilian Archives of Biology and Technology 48: 26-23. 2005.

Santos, G.P.; Zanuncio, J.C.; Anjos, N.A. (1982), Novos resultados da biologia de Psorocampa denticulata Schaus (Lepidoptera: Notodontidae), desfolhadora de eucalipto. Revista Árvore, 6, 121132.

Santos, G.P.; Anjos, N.; Zanuncio, J.C.; Oliveira, A.C.; Alves, A.P. (1985), Biologia de Apatelodes sericea Schaus (Lepidoptera. Eupterotidae), desfolhador de eucalipto. Revista Árvore, 9, 171-179.

Zanuncio, J.C.; Santos, G.P.; Batista, L.G.; Gasperazzo, W.L. (1992), Alguns aspectos da biologia de Dirphia rosacordis (Lepidoptera: Saturniidae) em folhas de eucalipto. Revista Árvore, 16, 112-117.

Zanuncio, T.V.; Zanuncio, J.C.; Meira, I.A.; Araújo, F.S. (1994), Caracterização das fases larval e adulta de Dirphia avicula (Lepidoptera: Saturniidae) em folhas de Eucalyptus urophylla. Revista Árvore, 18, 153-158.

Zanuncio, T.V.; Zanuncio, J.C.; Torres, J.B.; Laranjeiro, A.J. (1995), Biologia de Euselasia hygenius (Lepidoptera, Riodinidae) e seu consumo foliar em Eucalyptus urophylla. Revista Brasileira de Entomologia, 39, 487-492.

Zanuncio, J.C.; Zanuncio, T.V.; Freitas, F.A.; Pratissoli, D. (2003), Population density of Lepidoptera in a plantation of Eucalyptus urophylla in the state of Minas Gerais, Brazil. Animal Biology, 53, 17-26.

Received: October 17, 2005; Revised: April 05, 2006; Accepted: April 10, 2007. 